\title{
Angka Paling Mungkin (Most Probable Number/MPN) Coliform Sampel Minuman Lidah Buaya Di Pontianak
}

\author{
Dian Purnama Sari ${ }^{1}$, Rahmawati ${ }^{1}$,Elvi Rusmiyanto P.W ${ }^{2}$ \\ Program Studi Biologi, Fakultas MIPA, Universitas Tanjungpura, Jl. Prof. Dr. H. Hadari Nawawi, Pontianak, \\ Email korespondensi: dianpurnamasaribio12@gmail.com
}

\begin{abstract}
Aloe vera drink is one of the processed drinks made from the aloe vera leaves, washed until the mucus is reduced and boiled with water. Good drinking water should not contain pathogenic bacteria or organisms that can endanger human health. Coliform is one of the bacteria that can cause disease in humans and is used as an indicator of the presence of pathogenic bacteria. This study aimed to find out the most probable number (MPN) Coliform bacterial in aloe vera drinks which has sold at the location of the sale on Budi Utomo Street, Pontianak City. Sampling used the random sampling method. The MPN test results obtained the lowest MPN/mL index value of $0.091 / \mathrm{mL}$ in the samples purchased at the minimarket, while the seven samples obtained at the sales location showed the highest MPN/mL index value of $>24.00 / \mathrm{mL}$. It showed that the eight samples reached over the normal limits listed in SNI 01-3839-1995 based on the Republic of Indonesia Ministry of Health No. 907 / MENKES / SK / VII / 2002 concerning the requirements and supervision of the quality of drinking water which is not more than $0 / 100 \mathrm{~mL}$.
\end{abstract}

Kata kunci :, Aloe vera drink, Coliform, MPN

\section{PENDAHULUAN}

Minuman tidak hanya bermanfaat bagi manusia, namun juga dapat menjadi tempat yang sangat baik bagi pertumbuhan bakteri patogen. Manfaat yang dapat diperoleh dari minuman yang dijaga kebersihannya yakni terhindar dari cemaran bakteri terutama yang bersifat patogen (Soemirat, 2002). Puryana et al. (2015) menyatakan bahwa minuman yang dijual pada warung kecil di pinggir jalan menjadi salah satu contoh produk yang menggunakan bahan tambahan pangan dan terkadang proses pengolahannya tidak sesuai dengan Standar Nasional Indonesia terutama sanitasi yang kurang diperhatikan, sehingga akan sangat mudah tercemar oleh bakteri. Sanitasi mempengaruhi proses produksi suatu produk, seperti faktor manusia, peralatan yang digunakan dan tempat produksi dilakukan. Salah satu contoh minuman yang dijual di pinggir jalan adalah minuman lidah buaya.

Minuman lidah buaya merupakan salah satu minuman olahan yang berbahan dasar daging pelepah yang kemudian dicuci hingga lendirnya berkurang dan direbus dengan air (Mawardiah, 2017). Tahapan pembuatan minuman lidah buaya adalah pertama mencuci pelepah hingga bersih dan dipisahkan antara kulit dan daging pelepah. Tahap selanjutnya pelepah dicuci hingga bersih dari lendir, setelah itu dipotong dadu. Daging pelepah yang telah dipotong kemudian direndam dengan air garam selama 20 menit dan dilakukan beberapa kali perendaman. Setelah daging pelepah terbebas dari lendir dan bau, langkah selanjutnya adalah perebusan lidah buaya selama 15 menit dan ditambah beberapa simpul daun pandan. Minuman lidah buaya dapat ditambahkan air gula agar minuman terasa lebih nikmat (Mawardiah, 2017).

Kualitas air bersih di Indonesia harus memenuhi persyaratan yang tertuang dalam peraturan Menteri KesehatanRINo.173/Men.Kes/Per/VIII/77(Widiya nti \& Ristiati, 2004). Bakteri golongan Coliform (fekal dan non fekal) merupakan bakteri yang umum digunakan sebagai salah satu indikator sanitasi pada air dan makanan. Keberadaan golongan Coliform fekal penting untuk diperhatikan karena merupakan indikasi adanya kontaminasi fekal. Beberapa penelitian telah menunjukkan bahwa banyak minuman yang dijual terkontaminasi bakteri golongan Coliform.

Jumlah bakteri golongan Coliform serta anggota spesies Escherichia coli dalam sampel minuman ditentukan dengan menggunakan uji MPN (Most Probable Number) sebagai perkiraan jumlah individu bakteri. Metode MPN yang memiliki limit kepercayaan $95 \%$ pada setiap nilai MPN. Satuan yang digunakan umumnya per $100 \mathrm{ml}$ atau per gram. Misalnya terdapat nilai MPN 10/gram dalam sampel air, artinya dalam sampel air tersebut 
diperkirakan setidaknya mengandung 10 Coliform pada setiap gramnya. Makin kecil nilai MPN, maka makin tinggi kualitas air tersebut (Alang, 2015).

Penelitan yang telah dilakukan oleh Putri dan Kurnia (2018) yang menyatakan bahwa ketujuh sampel es dung-dung yang dijual di sekitar kampus Universitas Muhammadiyah Surakarta positif mengandung bakteri golongan Coliform dengan nilai indeks MPN yang sama yakni $>2400 / 100 \mathrm{ml}$. Penelitian yang dilakukan oleh Prayekti (2017) yang menyatakan bahwa kesembilan sampel minuman positif mengandung bakteri golongan Coliform dengan nilai indeks MPN tertinggi yaitu pada sampel nomor 3 dan 7 yakni sebanyak $>1600 / 100 \mathrm{ml}$. Menurut Khotimah (2016) standar mutu minuman yang dikatakan baik atau layak untuk dikonsumsi adalah 0/100ml berdasarkan SNI dan Kemenkes RI No. 907/MENKES/SK/VII/2002.

Perlu dilakukan penelitian kandungan bakteri golongan Coliform pada minuman khas Kalimantan Barat. Minuman lidah buaya banyak dijual di lokasi penjualan Jalan Budi Utomo yang merupakan daerah dekat lokasi perkebunan lidah buaya di Kalimantan Barat. Oleh karena itu perlu dilakukan penelitian untuk mengetahui cemaran bakteri golongan Coliform pada minuman lidah buaya yang dijual di lokasi penjualan Jalan Budi Utomo Kota Pontianak Kalimantan Barat. Berdasarkan informasi yang diperoleh dari penjual yang menyatakan bahwa air yang ditambahkan pada minuman lidah buaya tidak dimasak terlebih dahulu (Mawardiah, 2017), sehingga berpotensi adanya bakteri patogen. Oleh karena itu perlu dilakukan penelitian untuk mengetahui kandungan bakteri Coliform pada minuman lidah buaya yang dijual di lokasi penjualan Jalan Budi Utomo Kota Pontianak berdasarkan nilai Angka Paling Mungkin (APM)/Most Probable Number (MPN).

\section{BAHAN DAN METODE}

\section{Waktu dan Tempat Penelitian}

Penelitian ini dilakukan selama 2 bulan, dimulai pada bulan Oktober sampai Desember 2017, yang mencakup pengambilan sampel di lapangan, pengujian sampel dan analisis data. Pengambilan sampel minuman lidah buaya dilakukan di tujuh titik lokasi penjualan minuman lidah buaya di jalan Budi Utomo Kota Pontianak. Penelitian ini dilakukan di Laboratorium Mikrobiologi, Jurusan Biologi, Universitas Tanjungpura, Pontianak.

\section{Bahan}

Bahan yang digunakan pada penelitian ini adalah Alkohol 70\%, akuades, Brilliant Green Lactose Bile Broth (BGLB), Lactose Broth (LB), spritus.

\section{Prosedur Kerja \\ Sterilisasi Alat}

Alat-alat kaca seperti cawan petri, gelas beker, gelas ukur dan tabung reaksi dicuci bersih terlebih dahulu kemudian dikeringkan lalu disterilisasi menggunakan autoklaf selama 15 menit dengan tekanan $2 \mathrm{~atm}$ dan suhu $121^{\circ} \mathrm{C}$ (Marlina,2008).

\section{Pengambilan Sampel}

Pengambilan sampel dilapangan dengan cara membeli langsung minuman lidah buaya di tujuh titik lokasi penjualan minuman lidah buaya di lokasi penjualan Jalan Budi Utomo, Pontianak. Tiga sampel diambil dari masing-masing penjual, sehingga terdapat 21 total sampel. Sampel yang telah didapatkan kemudian dimasukkan kedalam cooling box lalu dibawa ke laboratorium Mikrobiologi, Fakultas Matematika dan Ilmu Pengetahuan Alam, Universitas Tanjungpura, Pontianak untuk dianalisis.

\section{Preparasi dan Pengenceran}

Tiga bungkus sampel yang telah dibeli dari masingmasing lokasi penjualan dikompositkan dengan mengambil masing-masing $100 \mathrm{ml}$ dari sampel dalam plastik tersebut dan dihaluskan menggunakan blender. Sampel sebanyak $10 \mathrm{ml}$ diambil dan dimasukkan ke dalam erlenmeyer yang berisikan 90 $\mathrm{ml}$ akuades sebagai suspensi. Suspensi sebanyak 1 $\mathrm{ml}$ diambil dan dimasukkan ke dalam tabung reaksi yang berisikan $9 \mathrm{ml}$ akuades sebagai pengenceran $10^{-1}$, kemudian dihomogenkan menggunakan vortex, lalu dengan cara yang sama dibuat pengenceran $10^{-2}$ dan $10^{-3}$ (Fardiaz, 1993).

\section{Deteksi Bakteri Coliform}

Pengujian dilakukan dengan menggunakan metode MPN melalui dua tahapan yakni tahapan pertama dilakukan uji penduga (Presumtif Test) lalu pengujian kedua dilakukan uji penegas (Confirmative Test) (Lay, 1994).

\section{Uji Penduga (Presumtif Test)}

Hasil pengenceran sampel $10^{-1}, 10^{-2}$ dan $10^{-3}$ diambil sebanyak $1 \mathrm{ml}$ dan dimasukkan masingmasing ke dalam 3 tabung yang berisi $9 \mathrm{ml}$ media Lactose Broth (LB). Kemudian setiap tabung yang berisi sampel diinkubasi selama 24-48 jam dengan suhu $37{ }^{\circ} \mathrm{C}$. Selanjutnya jumlah tabung yang terdapat gas diamati dan dicatat lalu dilakukan uji penegas.

\section{Uji Penegas (Confirmative Test)}

Sampel di dalam tabung diambil sebanyak 1 ose, dan dimasukkan ke dalam tabung yang berisi $9 \mathrm{ml}$ media Brilliant Green Lactose Bile (BGLBB) dan 
dilengkapi dengan tabung durham terbalik. Semua tabung diinkubasi pada suhu $37{ }^{\circ} \mathrm{C}$ selama $24-48$ jam. Pengujian dapat dinyatakan positif jika terbentuk gas atau gelembung dalam tabung durham. Jumlah tabung yang terbentuk gas pada uji penegas dicatat dan disesuaikan dengan tabel Most Probable Number (MPN). Jumlah angka yang didapatkan pada tabel MPN menunjukkan jumlah bakteri golongan Coliform dalam tiap $100 \mathrm{ml}$ sampel yang diujikan.

\section{Analisis Data dan Penyajian Data}

Penelitian yang dilakukan ini bersifat observatif dan deskriptif. Data yang diperoleh ditabulasi dan dideskripsikan dengan menampilkan tabel dan foto serta pengamatan kondisi lingkungan tempat pedagang berjualan.

\section{Hasil}

Uji penduga (Presumtive test) Coliform pada Sampel Minuman Lidah Buaya

Berdasarkan hasil uji penduga dari total 7 (tujuh) sampel dan 1 sampel pembanding penelitian dengan 3 (tiga) tingkat pengenceran, seluruhnya menunjukan adanya kandungan bakteri golongan Coliform. Hal ini ditunjukkan oleh hasil tes yang seluruhnya muncul gelembung pada tabung durham serta perubahan warna media yang sebelumnya bening menjadi keruh (Gambar 2).

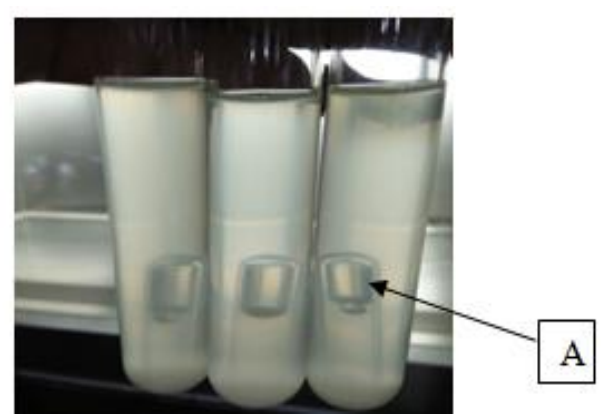

Gambar 2: Hasil uji penduga (Presumtive test) Coliform pada sampel minuman lidah buaya

Keterangan : $\mathrm{A}=$ hasil uji positif ditandai adanya gelembung pada tabung durham.

Uji Penegas (Confirmative Test) Coliform pada Sampel Minuman Lidah Buaya

Berdasarkan hasil uji penegas dari total 7 (tujuh) sampel penelitian dengan 3 (tiga) tingkat pencairan seluruhnya menunjukan adanya kandungan bakteri golongan Coliform. Hal ini ditunjukkan oleh hasil tes yang seluruhnya terdapat gelembung pada tabung durham serta perubahan warna media yang menjadi keruh (Gambar 3).

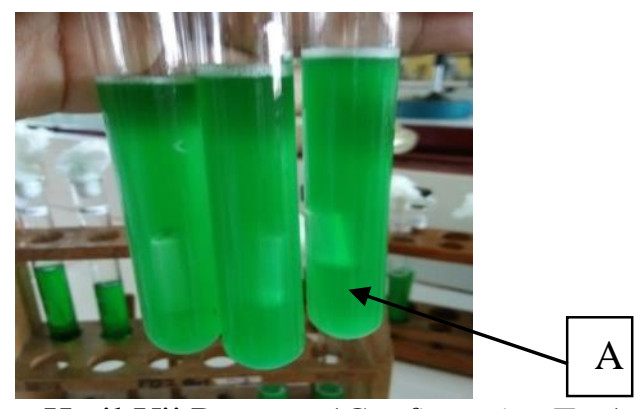

Gambar 3: Hasil Uji Penegas (Confirmative Test) Coliform pada sampel minuman lidah buaya.

Keterangan : A = hasil uji positif ditandai adanya gelembung pada tabung durham.

Nilai Most Probable Number (MPN) Minuman Lidah Buaya

Tabel 4.2 Tabel Most Probable Number (MPN) Minuman Lidah Buaya

\begin{tabular}{cccc}
\hline Sampel & $\begin{array}{c}\text { Coliform } \\
\text { (MPN/ } \\
\text { 100mL) }\end{array}$ & $\begin{array}{c}\text { Standar } \\
\text { Coliform } \\
\text { (MPN/ } \\
\text { 100mL) }\end{array}$ & Keterangan \\
\hline Sun Vera & 9,1 & 0 & TMS \\
Sampel 1 & $>1100$ & 0 & TMS \\
Sampel 2 & $>1100$ & 0 & TMS \\
Sampel 3 & $>1100$ & 0 & TMS \\
Sampel 4 & $>1100$ & 0 & TMS \\
Sampel 5 & $>1100$ & 0 & TMS \\
Sampel 6 & $>1100$ & 0 & TMS \\
Sampel 7 & $>1100$ & 0 & TMS \\
Keterangan: TMS $=$ Tidak memenuhi syarat \\
MS $=$ Memenuhi syarat
\end{tabular}

\section{Pembahasan}

Berdasarkan hasil uji MPN yang telah dilakukan menunjukkan bahwa semua sampel uji positif mengandung bakteri Coliform (Tabel 2). Uji MPN menunjukkan bahwa kedelapan sampel telah melebihi batas normal yang tercantum pada SNI 013839-1995 berdasarkan Kemenkes RI No. 907/MENKES/SK/VII/2002 tentang syarat-syarat dan pengawasan kualitas air minum adalah 0/100mL (Khotimah, 2016). Sampel minuman lidah buaya merk dengan kode SV (sampel pembanding berupa minuman lidah buaya kemasan yang dibeli di minimarket yang berada di sekitar Jalan Budi Utomo) memiliki nilai indeks $\mathrm{MPN} / \mathrm{mL}$ terendah yakni $0,091 / \mathrm{mL}$, sedangkan tujuh sampel lainnya yang memiliki nilai indeks MPN/mL tertinggi yakni $>24,00 / \mathrm{mL}$. Meskipun sampel SV yang merupakan sampel pembanding dalam penelitian ini dijual di minimarket dan telah dikemas dengan baik dibanding sampel minuman lidah buaya yang di jual di warung yang terdapat di pinggir jalan Budi Utomo, ternyata juga dapat terkontaminasi bakteri golongan Coliform. Hal ini diduga dapat disebabkan karena sampel yang memiliki nomor P-IRT ini 
mengalami proses pengolahan produk yang kurang higienis dan peralatan pengolahan skala rumah tangga, sehingga kemungkinan terkontaminasi bakteri golongan Coliform masih ada walaupun sedikit.

Menurut Dwi dan Mustarichie (2018), sertifikat PIRT yang merupakan ijin edar produk olahan yang diproduksi untuk dipasarkan secara lokal dan diperuntukkan hanya pada produk olahan dengan tingkat resiko rendah. Sertifikat ini diberikan kepada pengusaha kecil dengan modal terbatas dan pengawasan diberikan oleh Dinas Kesehatan Kabupaten/Kota setempat yang hanya sebatas penyuluhan. Oleh karena itu, sangat memungkinkan sampel minuman lidah buaya dengan kode SV ini masih memiliki resiko terkontaminasi oleh bakteri. Namun terdapat pula produk-produk yang memiliki izin BPOM bisa lebih aman dari bakteri yang dapat membahayakan kesehatan seperti bakteri Coliform. Sebagai contoh produk-produk yang aman misalnya produk-produk Nestle, baik yang diimpor langsung maupun yang dikemas ulang di Indonesia. Menurut Dwi dan Mustarichie (2018), produk-produk yang aman dari bakteri berbahaya seperti bakteri Coliform tersebut dapat dikarenakan produk pabrik tersebut telah mendapatkan izin BPOM pada tingkatan lebih tinggi daripada P-IRT, yakni izin BPOM ML (Makanan Luar). Perizinan ML merupakan nomor izin yang dikeluarkan dari BPOM untuk industri makanan dan minuman besar dan berasal dari luar negeri atau impor. Selain jaminan keamanan makanan yang akan dikonsumsi, kode ML juga menandakan bahwa makanan dan minuman tersebut telah secara legal dan resmi masuk ke Indonesia.

Berdasarkan hasil observasi menunjukkan bahwa ketujuh tempat penjualan melakukan proses sanitasi yang kurang baik seperti pada penanganan dan pengolahan sampel, penggunaan peralatan yang tidak bersih karena dicuci menggunakan air parit dan pada air campuran lidah buaya yang sudah direbus digunakan air hujan. Soemirat (1994) menyatakan bahwa sumber air hujan merupakan sumber air minum terlindung, kualitas air hujan tergantung pada kualitas udara yang dilaluinya sewaktu turun kembali ke permukaan bumi. Namun pada proses pembuatan sampel minuman lidah buaya, air hujan yang digunakan sebagai campuran lidah buaya yang telah direbus merupakan air hujan yang belum dimasak, sehingga kemungkinan air terkontaminasi bakteri akan lebih besar. Menurut Rezavie (2009), kontaminasi pada air minum bisa diakibatkan oleh terkontaminasinya air baku, tangan, peralatan dan pakaian pekerja serta higienitas buruk. Air pencucian peralatan yang menggunakan air parit sangat mempengaruhi kontaminasi bakteri Coliform karena lokasi parit yang dekat dengan pemukiman warga sehingga air parit tersebut tidak dapat digunakan begitu saja karena jarak antara pembuangan limbah rumah tangga dan penampung feses dengan sumber air cenderung berdekatan serta kebiasaan penduduk di tepian sungai membuang urin dan feses secara tidak langsung ke sungai menyebabkan terjadinya pencemaran bakteri golongan Coliform seperti bakteri anggota spesies Escherichia coli, Klebsiella dan Citrobacter.

Selain itu kontaminasi mikroba dapat pula disebabkan karena jarak lokasi penjualan minuman ini dengan jalan raya terlalu dekat sehingga kemungkinan kontaminasi bakteri yang berasal dari partikel debu di udara serta asap dari kendaraan yang melintas di depan lokasi penjualan dapat terjadi. Menurut Laluraa et al. (2014) bahwa penjual yang menggunakan peralatan yang tidak bersih dan berulang-ulang serta hanya diletakkan di ruang terbuka dapat memacu terjadinya kontaminasi mikroba. Pernyataan ini didukung oleh Faridz (2007) yang menyatakan bahwa kotoran yang tertinggal pada peralatan yang berasal dari sisa-sisa makanan atau minuman yang masih menempel dan debu dari polusi udara akibat penyimpanan peralatan pada ruang terbuka.

Penyebab lain kontaminasi bakteri dapat terjadi karena penjual tidak menggunakan peralatan yang sesuai dengan prinsip sanitasi saat melayani konsumen maupun saat melakukan proses pembuatan minumana lidah buaya. Prinsip sanitasi yang harus diterapkan oleh penjual yaitu menggunakan masker, baju khusus yang ringan dan menyerap keringat atau dapat menggunakan celemek lalu menggunakan sarung tangan serta mengikat rambut. Hal ini sesuai dengan pernyataan Nurmawati et al. (2009) bahwa karyawan atau penjual wajib menggunakan masker, baju khusus yang ringan dan menyerap keringat lalu menggunakan sarung tangan serta ikat rambut untuk menghindari terjadinya kontaminasi pada saat proses pembuatan minuman. Dengan demikian, dapat dikatakan bahwa kontaminasi bakteri pada makanan maupun minuman dapat terjadi karena berbagai faktor, mulai dari saat penyedian bahan baku, proses pengolahan, hingga penyajian dan pemasaran.

\section{DAFTAR PUSTAKA}

Alang, H, 2015, 'Deteksi Coliform Air PDAM di Beberapa Kecamaatan Kota Makassar', Prosiding Seminar Nasional Mikrobiologi Kesehatan dan Lingkungan, ISBN 978-60272245-0-6 
Dwi, MY \& Mustarichie R, 2018, 'Tata Cara Registrasi untuk Pangan Olahan Industri Rumah Tangga (PIRT) dan Makanan dalam Negeri (MD) dalam Rangka Peningkatan Produk yang Aman dan Bermutu', Bandung, Jawa Barat

Fardiaz S, 1993,'Analisis Mikrobiologi Pangan', Raja Grapindo Persada, Jakarta, hal : 306

Faridz, R, Hafiluddin \& M, Anshari, 2007, 'Analisis Jumlah Bakteri dan Keberadaan Escherichia coli pada Pengelolahan Ikan Teri Nasi PT. Kelola Mina Laut Unit Sumenep', Skripsi, Universitas Trunojoyo, Madura

Khotimah, L, 2016, 'Analisis cemaran bakteri coliform dan identifikasi Escherichia coli pada es batu kristal dan es balok di Kelurahan Cibubur Jakarta Timur Tahun 2016', Skripsi, Fakultas Kedokteran dan Ilmu Kesehatan Program Studi Farmasi, Jakarta

Laluraa LFH, Lohoo, H \& Hanny, WM, 2014, 'Identifikasi Bakteri Escherichia coli pada Ikan Selar (Selaroides sp.) Bakar di Beberapa Resto di Kota Manado', vol. 2, no. 1, hal. 10-13

Lay, BW, 1994, "Analisis Mikroba di Laboratorium", Jakarta : Rajawali

Marlina, 2008, Identifikasi Bakteri Vibrio parahaemolitycus dengan Metode Biologi dan Deteksi Gentoxrnya secara PCR, Jurnal Sains dan Teknologi Farmasi vol. 13, no. 1, hal. 1117

Mawardiah K, 2017, 'Tahapan Pembuatan Minuman Lidah Buaya', Pengamatan di Lapangan, Pontianak

Nurmawati, F, Mifbakhuddin, SR, Wardani, 2009, 'Hubungan antara hygiene perorangan petugas dan sanitasi depo air minum isi ulang dengan jumlah bakteri coliform di Kelurahan Sendang Mulyo Kota Semarang', Skripsi, Fakultas Kesehatan Masyarakat, Universitas Muhammadiyah, Semarang

Prayekti, E, 2017, 'Analisis Mikrobiologi Jajanan Minuman di Sekitar Sekolah Dasar pada Wilayah Jemurwonosari, Surabaya', Jurnal Sain Health, vol.1, no.2, p-ISSN : 2548-8333

Putri, AM \& Kurnia P, 2018, 'Identifikasi Keberadaan Bakteri Coliform dan Total Mikroba dalam ES Dung-dung disekitar Kampus Universitas Muhammadiyah,' Surakarta, Jurrnal Media Gizi Indonesia, vol.13, no.1, hlmn 41-48

Puryana IGPS, Agustini NP \& Kusumajaya AN, 2015, 'Cemaran MikrobaE.colipada Es Dalumanyang Dijual di Kota Denpasar', Jurnal Skala Husada, Vol 12 No 1 hal : 79-84

Rezavie TR, 2009, 'Kontaminasi Bakteri Escherichia coli pada Produk Depot Air Minum di Kecamatan Pancoran Mas Depok', Skripsi, Depok, Universitas Indonesia
Soemirat, 2002,'Kesehatan Lingkungan', Cetakan ke-5, Gadjah MadaUniversity Press, Yogyakarta

Soemirat J, 1994, 'Kesehatan Lingkungan ', Mutiara Sumber Widya, Jakarta

Widiyanti NLPM, Ristiati NP, 2004, 'Analisis Kualitatif Bakteri Koliform pada Depo Air Minum Isi Ulang di Kota Singaraja Bali',Jurnal Ekologi Kesehatan, Vol 3 No 1 hal : 64-73 